\title{
The Reappearing Judge
}

\author{
Steven S. Gensler ${ }^{*}$ \& Lee H. Rosenthal ${ }^{* *}$
}

Observers from both the bench and bar have criticized federal judges for spending too much time working alone in their chambers and not enough time working with lawyers and litigants. In an essay written for the 2010 Duke Conference on Civil Litigation, Judge Patrick Higginbotham lamented that district judges today spend so little time interacting with the public that their "faces" have faded from view. ${ }^{1}$ Judge William Young has long criticized what he sees as the shift of judicial work from the visible courtroom to the invisible back room. ${ }^{2}$ In an effort to counteract that phenomenon, he recently proposed that "bench presence" be added to the criteria for evaluating judges. ${ }^{3}$ It is not just judges who feel a growing sense of separation. Throughout our many years of involvement in the rulemaking process, we have talked to lawyers throughout the country about the state of the federal civil pretrial system. A recurring complaint is that lawyers often have little or no direct contact with the judges in charge of their cases.

Several factors seem to be fueling the impression that federal trial judges, while needing some detachment in order to ensure disinterest,

* Welcome D. \& W. DeVier Pierson Professor, Associate Dean for Research and Scholarship, University of Oklahoma College of Law.

** United States District Judge, Southern District of Texas. We thank the University of Kansas School of Law and the Kansas Law Review for their excellent work hosting and publishing this Symposium. These are our personal views, and not the views of any of the rulemaking committees on which we have served.

1. Patrick E. Higginbotham, The Present Plight of the United States District Courts, 60 DUKE L.J. 745, 745 (2010).

2. See William G. Young, A Lament for What Was Once and Yet Can Be, 32 B.C. INT'L \& COMP. L. REV. 305, 311 (2009) (lamenting the diminished role of the jury in the face of fewer jury trials); William G. Young, Vanishing Trials, Vanishing Juries, Vanishing Constitution, 40 SUFFOLK U. L. REV. 67, 73-74 (2006) (citing Patricia Wald, Summary Judgment at Sixty, 76 TEX. L. REV. 1897,1897 (1998)) ("[T]oday we are more concerned intellectually with the procedural mechanism that blocks jury trials than we are with the trials themselves."); William G. Young, An Open Letter to U.S. District Judges, 50 FED. LAW. 30 (2003).

3. See William G. Young \& Jordan M. Singer, Bench Presence: Toward a More Comprehensive Model of Federal District Court Productivity, 118 PENN. ST. L. REV. (forthcoming 2013); see also William G. Young \& Jordan M. Singer, Measuring Bench Presence: Federal District Judges in the Courtroom, 2008-2012, 118 PENN. ST. L. REV. (forthcoming 2013). 
have as a group become too remote and too absent from the public arena. One of those factors surely is the steady decline in civil trial rates during the past several decades, commonly referred to as the "Vanishing Trial." When the Federal Rules of Civil Procedure were adopted, the civil trial rate was approximately $20 \%{ }^{5}$ It has dropped steadily and precipitously since then. By the 1970s it had dropped to under $10 \%{ }^{6}$ By the middle of the $1980 \mathrm{~s}$, it dropped to under $5 \%{ }^{7}$ In 2012, the civil trial rate in the federal courts was just $1.2 \%{ }^{8}$ Observers continue to debate why so few civil cases go to trial. ${ }^{9}$ Whatever the reasons, the paucity of civil trials contributes prominently to the sense that federal district court judges no longer work in the public's eye. ${ }^{10}$

Another contributing factor, we suspect, is the arrival of the computer age - and with it the transition to the federal court's $\mathrm{CM} / \mathrm{ECF}$ electronic case filing system. Universal electronic filing has meant that the parties' submissions flow invisibly into the courthouse. Sometime later a judge's written order or decision emerges. All this occurs seemingly without human hand or voice. There are many virtues to the process, but it does contribute to a sense of isolation.

The rise of judicial case management in the federal courts also gets its share of the blame. In the 1970s, judges started applying to their ordinary civil cases management techniques developed for complex litigation. ${ }^{11}$ In 1983, case management became part of the Civil Rules

4. See, e.g., Marc Galanter, The Vanishing Trial: An Examination of Trials and Related Matters in Federal and State Courts, 1 J. EMPIRICAL LEGAL STUD. 459, passim (2004); Patricia Lee Refo, The Vanishing Trial, 1 J. EMPIRICAL LEGAL STUD. at v, v (2004) (discussing "The Vanishing Trial" project undertaken by the American Bar Association Section of Litigation).

5. Ellen E. Sward, The Decline of the Civil JuRy 12-13 (2001); Steven C. Yeazell, The Misunderstood Consequences of Modern Civil Process, 1994 WIS. L. REV. 631, 633 n.3.

6. Galanter, supra note 4, at 533 tbl. A-2.

7. Id. at 534 tbl.A-2.

8. Administrative OfFice of the United States Courts, Annual Report of the Director: Judicial Business of THE United STATES CourTs, tbl.C-4 (2012) (reporting case terminations during the twelve-month period from October 1, 2011 to September 30, 2012). During that period, there were 271,385 civil case terminations, of which just 3,212 terminated during or after trial. Id. Of that group, there were 993 nonjury trials and 2,219 jury trials. If one is counting only civil jury trials, then the trial rate in 2012 was just $0.82 \%$. Id.

9. See infra Part II.A. For a discussion of possible factors, see Marc Galanter, The HundredYear Decline of Trials and the Thirty Years War, 57 STAN. L. REV. 1255, 1262-68 (2005) (attributing the rapid period of decline during the past thirty years to "the ascendance of a judicial ideology that commends intensive judicial case management and active promotion of settlement").

10. Trial rates have declined in the state courts as well. See Galanter, supra note 4, at 506-10; Brian J. Ostrom et al., Examining Trial Trends in State Courts: 1976-2002, 1 J. EMPIRICAL LEGAL STUD. 755, 770-72 (2004).

11. Steven S. Gensler, Judicial Case Management: Caught in the Crossfire, 60 DuKE L.J. 669, 
canon when Rule 16 was amended to specifically authorize federal judges to actively manage their civil cases from start to finish and to specify particular tools for doing so. ${ }^{12}$ In the thirty years since, the rulemakers time and again have turned to case management, adding more tools to the rulebook to combat excessive cost and delay, especially in discovery. ${ }^{13}$

At the time of the 1983 amendments, some objected to the developing trend towards judicial case management. Judges who managed their cases were labeled "managerial judges." "14 The label was not meant as a compliment. Instead, it conveyed the sense that judges who managed their cases were engaged in an invisible process driven by an obsession with case disposition by any means available, including coerced settlements. ${ }^{15}$ Some commentators continue to worry that the advent of "managerial judging" has transformed federal trial court judges from public actors presiding over live courtroom proceedings into backroom negotiators and cloistered paper pushers. ${ }^{16}$

Is the situation really that bleak? Have federal trial court judges become mere administrators clothed in fancy robes? Have they disappeared from public view? Have lawyers lost their access to federal trial court judges, and as a result lost the opportunities for live advocacy that only such access can afford? And, most importantly, is there something about the current federal civil pretrial scheme that inevitably and inexorably isolates trial court judges from the public and drives them into seclusion?

670 (2010); see Jay Tidmarsh, Pound's Century, and Ours, 81 Notre Dame L. Rev. 513, 567-68 (2006) (discussing the origins of judicial case management).

12. See FED. R. CIV. P. 16 advisory committee's note to the 1983 amendment (discussing scope of amendments and their purpose). While Rule 16 has been in the Civil Rules from the start, as originally written its focus was on the period of time immediately preceding trial, the period that we now call "final pretrial." See Lee H. Rosenthal, From Rules of Procedure to How Lawyers Litigate: 'Twixt the Cup and the Lip, 87 DENV. U. L. REv. 227, 234 (2010); David L. Shapiro, Federal Rule 16: A Look at the Theory and Practice of Rulemaking, 137 U. PA. L. REV. 1969, 1981 (1989).

13. Gensler, supra note 11, at 679-83 (discussing the amendments that followed).

14. Judith Resnik, Managerial Judges, 96 HARV. L. REV. 374, 378 (1982)

15. Id. at 380 .

16. See Joseph F. Anderson, Jr., Where Have You Gone, Spot Mozingo? A Trial Judge's Lament Over the Demise of the Civil Jury Trial, 4 FED. CTS. L. REV. 99, 105 (2010) (asserting that the case management practices "preached by the Administrative Office" have led judges to view trials as a failure of the judicial system); Higginbotham, supra note 1, at 759; D. Brock Hornby, The Business of the District Courts, 10 GREEN BAG 2D 453, 462 (2007) ("For federal civil cases, the black-robed figure up on the bench, presiding publicly over trials and instructing juries, has become an endangered species, replaced by a person in business attire at an office desk surrounded by electronic assistants."). 
We have written this essay to offer a different, more hopeful view. It is true, of course, that many aspects of the civil pretrial process necessarily involve "chambers" work. But when we look at the current scheme, we see one that is flush with opportunities for live interactions and exchanges between judges and lawyers. We see extraordinary potential for reconnecting trial judges with lawyers and the litigants they represent. We see important opportunities for lawyers to be advocates for their clients in live proceedings before judges. We see a civil pretrial process in which the best case-management practices make trial judges more visible, not less, and the case-management tools more effective as a result.

This essay proceeds in two parts. In Part I, we argue that the best case-management practices increase the judge's public presence by creating additional opportunities for live interactions between the judge and the parties and counsel. These practices include holding "live" and robust Rule 16 conferences, conducting premotion conferences for discovery disputes and summary-judgment motions, and hearing oral argument on dispositive or other important motions. The common thread is that these are all platforms for dialogue that allow the judge, counsel, and parties to ask for and get information, clarify positions, identify what is truly in dispute, and separate what is important or urgent to resolve from what can be dispensed with or deferred. These practices are all platforms for interaction that take far less time and can be far more informative than the formal exchange of written motions and briefs. And, central to the theme of this essay, these practices all serve to reconnect judges with the parties and counsel. To put it in the terms framed by Judge Young, judges who embrace these case-management practices increase their "bench presence" rather than decrease it.

In Part II, we address two subjects that intersect with our vision of the Reappearing Judge. First, we believe that reappearing judges may help trials reappear, or at least slow the continued decline. Contrary to some longstanding speculation, judicial case management is not the enemy of the civil trial. Our claim here is necessarily modest. We do not claim that active judicial case management will return us to the trial levels of yesteryear. As others have established, settlement will be the rational outcome in the vast majority of cases in a system where the parties can be forced to turn their cards over before trial. ${ }^{17}$ But within that small set of civil cases in which trial is a realistic possibility, a key

17. See infra notes $63-71$ and accompanying text. 
determinant of whether the case will make it to trial is cost. Can the parties afford to get the case to trial, or will they feel forced to settlenot because of any shared sense of the merits but because the litigation costs exceed what the case is worth? Active case management is the best hope for ensuring that those civil cases that have any hope of going to trial can get there without becoming overwhelmed by uncontrolled pretrial costs.

Part II also considers the role that lawyers must play in a pretrial process in which the trial judge has reappeared. The live casemanagement interactions we advocate are not one-way events during which the judge does all or most of the talking. Rather, the value of these live interactions is that they are an opportunity for the judge and the lawyers to have an informed dialogue that penetrates the surface and exposes what matters most in the case or the issue to be decided. This dialogue can be valuable, whether it is about what discovery should take place when; how to resolve a discovery dispute; what a proposed summary-judgment motion will cover; or what evidence and arguments are most important to deciding that motion. For these interactions to be most effective, lawyers must view them not as a disruption to their usual case-development practices but as opportunities for skilled and effective advocacy. A willingness to prepare for, and exploit, the opportunities that live interactions with the judge provide is critical to the effectiveness of an interactive pretrial process. No matter how persuasive the argument for judicial case management might be initially, judges willand should - do it only if it proves to be worth their time.

We want to be perfectly clear about what we are saying - and not saying. We are not saying that either judicial case management or the civil pretrial process is a substitute for trials. Trials continue to have a critical and unique role in the American justice system. If we could snap our fingers and double the number of civil trials, we would. Nor are we saying that pretrial lawyer advocacy is a substitute for trial advocacy; each calls for related, but different, skill sets. Finally, we are not denying that the way many judges implement modern judicial casemanagement practices can lead to further isolation. Nothing in the Civil Rules obligates a federal trial judge to hold any of the live interactions we will be discussing shortly. It is possible for a judge to conduct the entire pretrial process on the papers without seeing or speaking with the parties or counsel. Our point is this: the current federal pretrial scheme is just as capable of supporting a public and interactive process as a removed and remote one. Trial judges who want to have live exchanges with counsel have ample opportunities throughout the pretrial process to 
do so. Judges do not have to choose between efficiently managing their cases and interacting with the lawyers or the parties. Judicial case management is not the natural enemy of public justice. The best casemanagement practices do not cause judges to vanish from view; they cause them to reappear.

\section{JUDICIAL CASE MANAGEMENT AND THE REAPPEARING JUDGE}

In 1983, the Federal Rules were amended to make explicit federal judges' authority to manage civil cases and to require judges to limit discovery to what is reasonable for each case. ${ }^{18}$ We didn't begin implementing these tools well. Instead, we began under a shadow of suspicion and skepticism about whether we should be actively managing cases with lawyers or maintaining our traditional roles of passivity and disengagement. ${ }^{19}$ We worried about becoming case bureaucrats rather than adjudicators, and about working on administration rather than jurisprudence. But over time, individualized case management took hold as a central feature of the federal civil pretrial process. ${ }^{20}$ And in the last few years, case management seems truly to have come into its own. It has shaken off some of the early doubts about whether it was good or worthwhile. $^{21} \quad$ There is a veritable explosion of work on case management, with pilot projects and proposals for new rules, protocols, and approaches in many federal and state courts. ${ }^{22}$ Just this spring, the

18. See FED. R. CIV. P. 16 advisory committee's note to 1983 amendment; Id. 26(b) advisory committee's note to 1983 amendment. See generally ARTHUR R. MiLler, FED. JUdiCIAL CTR., THE August 1983 Amendments to the Federal Rules of Civil Procedure: Promoting EFFECTIVE CASE MANAGEMENT AND LAWYER RESPONSIBILITY 30-36 (1984) (discussing purposes behind the 1983 amendments); Gensler, supra note 11 at 676-78 (2010) (discussing 1983 amendments); Richard L. Marcus, Reducing Court Costs and Delay: The Potential Impact of the Proposed Amendments to the Federal Rules of Civil Procedure, 66 JUDICATURE 363, 365-69 (1983) (discussing 1983 amendments).

19. See, e.g., Resnik, supra note 14, at 379-80 (1982) (criticizing the 1983 amendments before those amendments were approved by the Supreme Court).

20. See Gensler, supra note 11, at 679-85 (discussing how developments after 1983 continued the movement toward case management).

21. When reporting on the events of the 2010 Duke Conference on Civil Litigation, Judge Mark Kravitz, the Chair of the Civil Rules Advisory Committee, remarked that "[p]leas for universalized case management achieved virtual, perhaps absolute, unanimity." See Memorandum from Judge Mark R. Kravitz, Chair, Advisory Comm. on Fed. Rules of Civil Procedure, to Judge Lee H. Rosenthal, Chair, Standing Comm. on Rules of Practice \& Procedure, Report of the Civil Rules Advisory Committee 8 (May 17, 2010), available at http://www.uscourts.gov/uscourts/Rules AndPolicies/rules/Reports/CV05-2010.pdf.

22. See Rule One Initiative: Implementation, IAALS, http://iaals.du.edu/initiatives/rule-oneinitiative/implementation (last visited Mar. 13, 2013) (providing a list of case management programs adopted by various state and federal courts); e.g., EmP'т Protocols Comm., Рilot Project 
Benchbook for U.S. District Court Judges was revised to include, for the first time, a new chapter on pretrial case management. ${ }^{23}$

What explains the change in attitude? One reason is the added cost and burden imposed by electronic discovery. These costs and burdens make it all the more vital to identify and enforce limits. ${ }^{24}$ Another reason may be increasing judicial comfort with using case-management tools. Yet another reason is that the computer has provided a host of ways to make it easier to use those tools. And there seems to be a growing sense of shared conviction that without effective judicial case management, the age-old problems of cost and delay will so frustrate lawyers and litigants that they will continue to leave the judicial system with fewer and fewer cases tried, or they will simply avoid the system altogether.

The renewed attention to case management lets us focus on how it can provide opportunities for interaction between lawyer and judge. What is this interaction? For the lawyer, it is live advocacy visible to the judge, not merely to opposing counsel and parties or witnesses. Live advocacy allows lawyers a chance to let the judge know and understand what really matters and what is reasonable for that case. And for the judge, it is the best source of the information necessary to manage a case effectively.

\section{A. What Do We Mean by "Case Management," Anyway?}

Case management has suffered from misconceptions about what it is and what it is not. One misconception is that case management is a process by which judges push reluctant parties to settle. ${ }^{25}$ We do not

REgarding Initial Discovery Protocols For EMPloyment CASES Alleging Adverse ACTION 2011, available at http://www.fjc.gov/public/pdf.nsf/lookup/discempl.pdf/\$file/discempl. pdf; Judicial Improvements Comm. of the S. Dist. of N.Y., Pilot Project Regarding Case Management Techniques for Complex Civil Cases [hereinafter S.D.N.Y. PILOt Project] (2011), available at http://www.nysd.uscourts.gov/rules/Complex_Civil_Rules_Pilot.pdf; Discovery Pilot: SeVEnth Circuit Electronic Discovery Pilot Program, http://www.discoverypilot.com/ (last visited Apr. 10, 2013).

23. See Federal Judicial Ctr., Benchbook for U.S. District Court Judges (6th ed. 2013) [hereinafter BENCHBOOK], available at http://www.fjc.gov/public/pdf.nsf/lookup/BenchbookUS-District-Judges-6TH-FJC-MAR-2013-Public.pdf/\$file/Benchbook-US-District-Judges-6TH-

FJC-MAR-2013-Public.pdf.

24. See, e.g., John H. Beisner, Discovering a Better Way: The Need for Effective Civil Litigation Reform, 60 DUKE L.J. 547, 564-70 (2010) (discussing increased costs associated with electronic discovery). See generally Nicholas M. PACE \& LAURA ZAKARAS, WHERE THE MONEY Goes: Understanding Litigant EXPENDITURES FOR PrODUCING ElECTRONIC Discovery 1-3 (2012) (discussing sources and support for the claim that electronic discovery presents new and higher costs).

25. See Todd D. Peterson, Restoring Structural Checks on Judicial Power in the Era of 
think that judges view settlement as the purpose of case management. ${ }^{26}$ To the contrary, effective case management means tailoring the pretrial work to what is reasonable and proportional to the case. Effective case management may provide a faster and less expensive way of getting the parties information they need to value the case, which may in turn facilitate settlement. ${ }^{27}$ But that is not pushing the parties to settle; that is allowing settlements that likely would have occurred later to get done earlier, with less work and less cost. ${ }^{28}$ The idea that settlement is an appropriate byproduct of case management-but not its purpose-goes back to Charles E. Clark and the original drafters of the Civil Rules. ${ }^{29}$

Another misconception is that case management is essentially about setting important deadlines that end with a trial date and then not moving from that date. Establishing reasonable and predictable deadlines is an important part of case management, but it is far from sufficient. Among other things, simply writing down dates does not tailor pretrial work to what the case demands; does not provide the judicial supervision that may be required for electronic discovery; and does not respond to the frequent complaints by lawyers that absent access to the judge when needed, they have no effective way to control excessive or obstructionist discovery practices, to avoid unnecessary and burdensome motions practice, or to control pretrial costs in general.

Managerial Judging, 29 U.C. DAVIS L. REV. 41, 75 (1995) (criticizing case management as a means by which judges coerce settlement); Resnik, supra note 14, at 424-31 (discussing coerced settlements as a byproduct, if not a purpose, of case management). While it is certainly true that some judges have at times used coercive settlement practices, the idea that these practices are widely used, or that their incidence justifies a wholesale skepticism of judicial case management, has been questioned from the start. See Steven Flanders, Blind Umpires-A Response to Professor Resnik, 35 HASTINGS L.J. 505, 507-14 (1984).

26. See Robert F. Peckham, A Judicial Response to the Cost of Litigation: Case Management, Two-Stage Discovery Planning and Alternative Dispute Resolution, 37 RUTGERS L. REV. 253, 267 (1985) ("The primary purpose of status and pretrial conferences is to plan and structure the pretrial and trial stages of litigation.").

27. See Peckham, supra note 26 , at 267 ("Case management simply brings cases to settlement or to trial sooner than if their progress were left entirely to the impetus of the parties."); Shapiro, supra note 12, 1980-81 ("Settlement, in what was probably the prevailing view of the time, might be a by-product of a well-run pretrial conference but should not be a primary goal.").

28. See Steven S. Gensler \& Lee H. Rosenthal, Managing Summary Judgment, 43 LOY. U. CHI. L.J. 517, 536 (2012) ("While the number of cases that settle is important to avoiding litigation expense, so too is the timing of those settlements.... We break no new ground in pointing out that the earlier a case settles, the greater the savings to the court and the parties.").

29. See Charles E. Clark, Objectives of Pre-trial Procedure, 17 OнIо ST. L.J. 163, 167 (1956) (explaining that the original drafters deliberately omitted mentioning settlement from their version of Rule 16 because while "settlement will come naturally in many cases as the issues are defined and made clear and simple," it would be "dangerous to the whole purpose of pre-trial to force settlements upon unwilling parties"). 
The most unhelpful misconception is that case-management work is bureaucratic, ministerial, and rote. To the contrary, case-management work presents opportunities for judges to be creative, imaginative, and helpful in working with lawyers and litigants. Case management lets judges work to devise practical solutions to pressing problems and to shape cases toward pretrial preparation that is reasonable and proportional to what each case requires. This is often considerably more productive and gratifying than issuing (yet another) opinion resolving a motion to dismiss or for summary judgment.

These opportunities for effective case-management interactions between lawyers and the judge exist at each stage of a case, typically beginning no later than the Rule 16 conference and ending with the final pretrial conference. The following section discusses some general approaches that let judges, lawyers, and litigants make the most of these opportunities. The common theme is that the judge has set up platforms to talk with the lawyers and manage the case based on an accurate, reliable, and adequate understanding of what makes sense for that case.

\section{B. Reappearing at the Rule 16 Initial Conference}

In most cases, the first opportunity for the trial judge to interact with the lawyers - and occasionally the parties - is at a live Rule 16 casemanagement conference. It is not just the first opportunity-it is the most important one. A live Rule 16 conference allows the judge and the parties to identify threshold legal issues, such as jurisdiction, venue, or limitations. The conference then allows the judge and parties to plan targeted or limited discovery needed to raise and resolve those issues, and through such staging, save time and money that would otherwise likely have been spent on potentially unnecessary full discovery and cover-the-waterfront motions practice. ${ }^{30}$ Such an exchange lets the court put in place a case-management order that sets a timeline tailored to the case, at least preliminarily defines and limits discovery, stages motions and related discovery if appropriate, and provides guidance and information that can reduce later disputes. ${ }^{31}$

A live Rule 16 conference is much more valuable for the judge than simply reading the parties' Rule 26(f) report. Those reports are too often the result of a "drive-by," perfunctory meeting between counsel, before

30. See Rosenthal, supra note 12, at 241-42.

31. Id. 
any initial disclosures have been exchanged. ${ }^{32}$ Even when the reports show some preparation and detail, they cannot replace what a live exchange between the court and counsel provides. ${ }^{33}$ Such an exchange lets the court ask questions about what the case really needs, probe the answers the lawyers provide, and press for missing or incomplete information. A live Rule 16 conference is also an ideal opportunity for the judge to convey expectations of how the parties should conduct themselves during the pretrial process. ${ }^{34}$

Here are three examples of some benefits that repeatedly present themselves during live Rule 16 conferences. First, in almost every written Rule 26(f) report, the lawyers state that they need expert witnesses and build in time for exchanging designations and reports, and for taking depositions. In many of these cases, no expert is needed. The live Rule 16 conference makes it easy for the judge to figure out if there is any need for an expert and, if not, to shorten the scheduling order. This often occurs in Title VII or Fair Labor Standards Act cases, in which the only likely expert testimony is on attorney's fees and, if needed, can be presented to the court by affidavit at the end of the case. A second and particularly gratifying example presents itself in the many cases recently flooding the federal courts in which mortgage holders seek to avoid foreclosure. A live-and only a live-Rule 16 conference allows the judge to explore whether the plaintiff is financially capable of paying a modified mortgage and, if so, whether the lender is willing to work toward that end. If the conference succeeds, the plaintiff stays in the home, a mortgage-payment plan is put in place, and the lawyers' time and effort has been spent on those goals rather than on formal discovery or motions. A third example of the benefits of the live Rule 16 conference is in the area of electronic discovery. The live Rule 16 conference allows the court to ensure that the lawyers and parties have paid appropriate attention to planning for electronic discovery and that, if needed, a reasonable, cost-effective, and efficient plan for preserving,

32. See Emery G. Lee III, Fed. Judicial Ctr., Early Stages of Litigation Attorney SURVEY 10 (Mar. 2012) (lawyers reported that only 9\% of Rule 26(f) meetings occur in person and that most Rule 26(f) meetings last less than ten minutes or between ten and thirty minutes).

33. See BENCHBOOK, supra note 23, at 193; Rosenthal, supra note 12, at 241-42.

34. For example, judges can use the initial Rule 16(b) case management conference to impress upon the parties and counsel that they are expected to cooperate with each other and the court to try to streamline the discovery process and avoid, where possible, the cost and delay associated with needless - and needlessly contentious - discovery disputes. See BENCHBOOK, supra note 23, at 197; see also Gensler, supra note 11, at 734-38 (discussing how judicial case management can be facilitated by attorney cooperation). 
requesting, retrieving, reviewing, and producing electronically stored information is in place or under way. ${ }^{35}$

Many judges worry that they do not have the time to spend on live Rule 16 conferences, given the rest of their docket demands. But in most cases, these conferences can accomplish a great deal in a relatively short time. In complex cases, judges generally agree that investing even significant time up front in working with the lawyers to craft a detailed case-management plan can save the court significant time and effort later in the case. Similar dividends exist in less complicated cases. The upfront investment is small; in ordinary litigation, it is the unusual conference that takes more than fifteen or twenty minutes. That small investment can save a great deal of judge-as well as lawyer and litigant - time and work later on. In many ways, it is the smaller cases that benefit the most from judicial management because they can least bear the costs of needless (and avoidable) discovery and motions practice. ${ }^{36}$ Judges also worry that it may be difficult for the counsel to attend live conferences, but there is flexibility. The term "live" does not necessarily mean "in person," although that is often preferable. If lawyers are distant or far-flung, telephones or teleconferencing can be used. And technology will make this both easier and more effective; it is easy to imagine judges and lawyers using voice-over-internet, Skype, or videoconferencing routinely in the near future.

Judges may also worry that neither they nor the lawyers have enough information early in the case to make a live Rule 16 conference helpful enough to be worthwhile. That risk can be reduced if the judge makes it clear to the lawyers in advance of the Rule 16 conference what the judge expects them to be prepared to discuss. Some judges send an order or statement of case-management guidelines along with the order setting the Rule 16 conference. ${ }^{37}$ Such early communications can help structure the

35. See BENCHBOOK, supra note 23, at 196; Rosenthal, supra note 12, at 241. This discussion is also a good opportunity to discuss the entry of a "non-waiver" order under Federal Rule of Evidence 502. See BENCHBOOK, supra note 23, at 195-96 (discussing benefits of Rule 502 orders); Rosenthal, supra note 12, at 241 (discussing benefits of Rule 502 orders).

36. See aba Section of litigation Member Survey on Civil Practice: Detailed REPORT 153-54 (2009) [hereinafter ABA SURVEY], available at http://www.uscourts.gov/ uscourts/RulesAndPolicies/rules/Duke\%20Materials/Library/ABA\%20Section\%20of\%20Litigation, $\% 20$ Survey\%20on\%20Civil\%20Practice.pdf (demonstrating through survey results that small cases are at special risk of having disproportionate litigation costs).

37. See Comm. on Court Admin. \& Case Mgmt., Judicial Conference of the U.S., Civil Litigation MANAGEMENT MANUAL 22-23 (2d ed. 2010) [hereinafter CiviL Litigation MANAGEMENT MANUAL] (discussing this practice); see also BENCHBOOK, supra note 23, at 191 (discussing potential benefits of initial case-management orders). 
parties' initial exchanges and activities and facilitate an effective Rule 16 conference with the court. The knowledge that the judge will be asking pointed questions in the Rule 16 conference about specific issues, motions, discovery, and deadlines often itself provides effective incentive for the lawyers to prepare. The relatively small amount of judge time needed to get sufficient early familiarity with the case to ask productive questions in the live Rule 16 conference pays ample dividends both in the short and the long term.

It is true, as some critics have noted, that in many cases neither the judge nor the parties will be in a position at the start of the case to know exactly where the boundary of proportional discovery ends. ${ }^{38}$ But judges can, with the parties' help, identify the areas where discovery should begin, focusing discovery on the core issues and targeting the best sources. $^{39}$ In many cases, the parties will find that is all they need. ${ }^{40}$ And if further discovery is sought, the judge will have the results of the initial discovery to help her decide where to draw the proportionality line.

Some cases may require more intensive or continuing management. One early Rule 16 conference may not suffice. These are likely to be cases in which it is clear early on that there will be disputes or uncertainties about discovery that will need ongoing, active judicial involvement if the case is to stay on track. Or there may be more information needed before an effective scheduling order or motions and discovery plan can be put in place. The judge can consider whether

38. See Frank H. Easterbrook, Discovery As Abuse, 69 B.U. L. ReV. 635, 638-39 (1989) (arguing that case management cannot work because judges do not have all the information they need to manage effectively); see also Robert G. Bone, Twombly, Pleading Rules, and the Regulation of Court Access, 94 IOWA L. REv. 873, 899-900 (2009) ("Judges face information and other constraints that impair their ability to manage optimally, especially in the highly strategic environment of litigation."); Martin H. Redish, Electronic Discovery and the Litigation Matrix, 51 DUKE L.J. 561, 603-04 (2001) (arguing that proportionality limits are impractical because the trial court is not in a good position to assess whether the desired information is worth the cost).

39. As Judge Peckham noted during the early days of the case-management movement, in most cases it makes no sense for the parties to immediately commit themselves to "full-blown discovery" because the disposition of most cases will turn on a set of core information. Peckham, supra note 26, at 269; see also Steven S. Gensler, A Bull's-Eye View of Cooperation in Discovery, 10 SEDONA CONF. J. 363, 371-72 (Supp. 2009) (discussing benefits available when the parties cooperate to identify the most productive and most cost-effective sources of discovery); Louis Kaplow, Multistage Adjudication, 126 HARV. L. REV. 1179, 1227 (2013) (discussing the potential benefits of staging discovery to begin with key documents and witnesses).

40. See Civil Litigation Management Manual, supra note 37, at 33-34 (discussing how targeted initial discovery can resolve issues or provide information that obviates the need for further discovery). 
follow-up or interim conferences should be held, by telephone or in person, to continue the dialogue. ${ }^{41}$

There is another reason why the initial Rule 16 conference is an optimal time for judges to interact with the lawyers and the parties: it comes at the start of the lawsuit, not the end. The point is basic. Very few cases will reach trial. ${ }^{42}$ Most cases will at least reach the initial casemanagement stage. ${ }^{43}$ If a goal is to reconnect judges and lawyers, then the most fertile ground for doing that is at the start of the case rather than the end.

In short, holding a live Rule 16 conference is the first - and we think the most essential - step to effective case management. But it is more than that. It is also the judge's first - and in many cases only - chance to let the lawyers (and sometimes the parties) see the face of the court, or at least hear its voice. We can think of no better way to start changing the perception that trial judges have become faceless figures dispensing impersonal justice from cloistered chambers than for judges to hold live Rule 16 conferences.

\section{Reappearing During Discovery: Premotion Conferences for Discovery Disputes}

Many judges - indeed, many districts - have moved to a system of premotion conferences to resolve discovery disputes. ${ }^{44}$ These conferences are generally held within a few days after the dispute arises and the party seeking relief contacts the case manager by email or telephone. The case manager sets a date-sometimes over a lunch hour or after the trial day ends - and the lawyers either appear in court or by telephone or teleconference. The premotion conference may be preceded

41. See BENCHBOOK, supra note 23, at 197-98 (discussing ongoing case-management strategies).

42. See supra note 8 and accompanying text (reporting a federal civil trial rate of $1.2 \%$ for 2012).

43. See LEE III, supra note 32 , at 13 (suggesting a $20 \%$ pre-Rule 16 resolution rate based on two pieces of data: first, that $50 \%$ of cases did not have a Rule $16(\mathrm{~b})$ conference and, second, that in $40 \%$ of those cases the reason was that the case resolved before the conference could take place).

44. See, e.g., S.D.N.Y. L. Cv. R. 37.2 ("No motion under Rules 26 through 37 inclusive of the Federal Rules of Civil Procedure shall be heard unless counsel for the moving party has first requested an informal conference with the Court by letter and such request has either been denied or the discovery dispute has not been resolved as a consequence of such a conference.”). Judge Rosenthal requires premotion conferences for discovery disputes in her standing procedures for civil cases. See Procedure 5.C.1, available at http://www.txs.uscourts.gov/district/judges $/ \mathrm{hr} / \mathrm{hhr}$.pdf ("The party wishing to make any discovery motion must arrange for a conference with the court before the preparation and submission of motion papers."). 
by a brief - one or two page-letter and response that sets out the topic of the dispute without any argument on the facts or the law. When the lawyers come to court or chambers for the premotion conference, the exchange is generally efficient and practical. ${ }^{45}$ The judge asks what the party seeking the discovery needs, and why. Often the answer is that the discovery needed is far more modest than what had earlier been sought. Hearing the answer to this general question and to follow-up questions, the judge then turns to the other party and asks why that party is unwilling to provide the discovery. The exchange is launched. And most of the time, the judge is able to rule from the bench, then and there, stating the reasons on the record. Even when the judge decides that there are issues that do require legal research or briefing, the conference greatly narrows the issues.

What is avoided through this process? The time-consuming, expensive, laborious minuet of: (1) the motion to compel or to quash, or for protection-with the lengthy brief accompanied by a thick stack of attached discovery requests and objections, and often the exchange of emails between counsel, each one more annoyed and annoying than the last; (2) the response brief, also with attachments and email exchanges; (3) sometimes, the reply; and (4) sometimes, the surreply. Even if the minuet stops at step two, that is two steps that can be avoided. What is gained? The case does not get derailed by the delay required for the parties to perform the minuet and for the judge to write an opinion explaining who wins, on what terms, and why. The parties are saved the often considerable expense of formally litigating the dispute. And the exchange allows the judge to check in on other work in the case and ensure that it is progressing efficiently and effectively.

There is one more thing that is gained. The conference provides another opportunity for the judge and the lawyers to interact in a live proceeding. It also provides the lawyers with an opportunity to act as live advocates for their clients. And when the conference is held in open court, the judge's accessibility to the lawyers and willingness to engage in resolving discovery disputes promptly and efficiently are publicly apparent.

45. See generally Rosenthal, supra note 12, at 242 (also discussing mechanics and benefits of premotion conferences for discovery disputes). 


\section{Reappearing Before Summary Judgment Motions are Filed: Expanding the Premotion Conference}

Some judges have expanded the premotion conference beyond discovery disputes. In cases where the lawyers expect to file summary judgment motions, these judges hold premotion conferences before that filing occurs. ${ }^{46}$ These conferences allow the judge to review with the lawyers what the scope and basis of the motion and the response are likely to be. ${ }^{47}$ That in turn allows the judge and lawyers to explore whether all or part of the motion can be avoided. ${ }^{48}$

An employment dispute presents an easy example. Many employment discrimination cases are pleaded to include an intentional infliction of emotional distress claim. The law of most states makes it very difficult to raise a fact dispute that would allow this claim to proceed to trial. Why should the parties or the court waste time and effort resolving that motion if the plaintiff's claim is clearly doomed to fail? And, conversely, if the disparate-treatment claim that is at the heart of the case clearly rests on contradictory testimony that can't be resolved without credibility judgments, a summary judgment motion is not likely to succeed.

A judge may not tell a party not to file a summary judgment motion. But a judge and the lawyer may well agree that some of the grounds could be dispensed with. And the conference allows the judge to gain a familiarity with the issues, a familiarity that will help when the motion is filed.

Some have expressed concern that it is hard to know enough about the case to know whether such a conference should be held and when it should be scheduled. But in many cases or categories of cases, it is clear early on that a motion for summary judgment will be filed on all or part of the claims or defenses. In many cases or categories of cases, it is also clear early on when, given the time other motions, discovery, or both will likely take, the summary judgment motion is likely to be filed. In many cases, a lawyer can email the judge's courtroom deputy, case manager or

\footnotetext{
46. See, e.g., CiVIL Litigation MANAGEMENT MANUAL, supra note 37, at 58 (listing prefiling conference as a possible management device). The Southern District of New York is currently requiring premotion conferences as part of its Pilot Project Regarding Case Management Techniques for Complex Civil Cases. See S.D.N.Y. PiLOT PROJECT, supra note 22.

47. See generally Gensler \& Rosenthal, supra note 28, 549-55 (extended discussion of premotion conference for summary-judgment motions).

48. Id. at $551-52$.
} 
coordinator, or judicial assistant, and ask for a premotion conference after the lawyer has decided to file a motion but before the bulk of the (often expensive) drafting and evidence-assembling work has been done. Scheduling has not proven difficult for those judges using this casemanagement tool.

There may be cases in which this conference is not needed or helpful, but the beauty of case management is that it is case-specific. The premotion conference held in advance of filing a summary judgment motion is a tool that can be selectively applied. When it makes sense to have such a conference, the judge can spend fifteen or twenty minutes talking to the lawyers, and in exchange avoid having to read all or a significant portion of motions, briefs, evidence, and responsive submissions. ${ }^{49}$ The lawyers avoid the time and expense of preparing those pages. ${ }^{50}$ And at a minimum, the judge knows the case better for the work that lies ahead, and the lawyers have more confidence in the judge's understanding of the issues. ${ }^{51}$

Last but not least, a premotion conference for potential summaryjudgment motions presents yet another opportunity for the judge and the lawyers to interact, either in chambers or the open courtroom. And as with premotion conferences for discovery disputes, a premotion conference for summary judgment gives the lawyers a chance to serve as live advocates for their clients, this time in a context that directly implicates the merits.

\section{E. Reappearing when Motions Are Needed: Oral Argument}

We often think of oral argument in the appellate-court model. There are traffic lights that drastically limit the lawyers' time. The three judges on a panel have to share the time to ask their questions. Oral argument in the trial court is far different. ${ }^{52}$ Oral argument in a one-judge court can take as much time as the judge thinks is helpful. It can be a lively exchange of questions, answers, and more questions. It can be thorough, searching, and truly helpful, to both lawyers and judges. Predictable benefits include avoiding the ships-passing-in-the-night phenomenon that too often characterizes the parties' briefs and can be a feature of the

\footnotetext{
49. See id. at 553.

50. See id. at 550-53 (discussing inefficiencies of traditional full-briefing model).

51. See id. at 553 .

52. See id. at 556 .
} 
judge's decision. ${ }^{53}$ The judge gets a more accurate understanding of what issues matter in the case. The parties' arguments and answers to the judge's questions may identify areas on which the parties agree, or agree do not matter, narrowing the judge's work. The judge obtains a more confident grasp of the factual record and of the law that applies. The judge can rehearse her understanding of the case, give the parties an indication of how the judge is leaning, and let the parties expose the flaws that might be present. Arguments that otherwise only surface in a motion to reconsider, or to alter or amend, can be aired. The appellate court has an additional source of insight into the parties' positions.

Despite these benefits, oral argument on motions is the clear exception to the rule. ${ }^{54}$ Lawyers typically do not ask for it, and judges typically do not offer. We think that is a missed opportunity on several levels. It is a missed opportunity from a case-management perspective. ${ }^{55}$ If the lawyers understand that they will be expected to go beyond the briefs and explore the case, it can be a productive and effective addition to case management. ${ }^{56}$ It can avoid the post-ruling motions that result when the parties' briefs did not accurately communicate the parties' arguments. And it is a missed opportunity for interaction and public judging. ${ }^{57}$ What better way to counteract the perception that judges are disposing of cases via a sterile and faceless paper process than to open up the courtroom, bring in the lawyers and the parties (if they wish), and hash out the arguments until an answer-or at least a clearer understanding of the problem - emerges from the dialogue?

53. See Mark R. Kravitz, Written and Oral Persuasion in the United States Courts: A District Judge's Perspective on their History, Function, and Future, 10 J. APP. PRAC. \& PROCESS 247, $262-$ 64 (2009) (discussing the unique benefits of hearing oral argument on dispositive motions).

54. A recent study found that on average $30 \%$ of summary-judgment motions received some type of hearing or oral argument, although the range was from $3 \%$ to $73 \%$ depending on the district. InST. For the Advancement of the Am. Legal Sys., Civil CASE Processing in the Federal DISTRICT COURTS 51 (2009).

55. See Gensler and Rosenthal, supra note 28 , at $555-58$.

56. Judges sometimes facilitate that understanding by sending out in advance questions they want the lawyers to focus on or raising issues the briefs did not address. See Civil Litigation MANAGEMENT MANUAL, supra note 37, at 53 (recommending that judges who schedule oral argument on motions consider "advising counsel of the particular issues on which you want oral argument"). But even without such advance preparation, oral argument on motions presents a platform for improved understanding of the case.

57. D. Brock Hornby, Summary Judgment Without Illusions, 13 GREEN BAG 2D 273, 284-85 (2010) (noting that holding oral argument takes the summary-judgment process "out of the back room" and puts a "human face" on it); Kravitz, supra note 53, at 263 ("Part of the reason that the English legal system has clung to oral argument is the English belief that justice must be seen in order to be done."). 


\section{F. Summary: Reappearing Together}

When you think of judicial case management, what words come to mind? For thirty years, many have associated case management with negative words like ministerial, bureaucratic, distant, and unavailable. For us, a very different set of words comes to mind. Interaction. Exchange. Engagement. Availability. These are good words. They describe the work of a judge who is visible to the lawyers - and of lawyers who are visible to the judge-despite litigation trends that increasingly send both into isolated rooms before isolating computer screens. Case management provides opportunities for judges and lawyers to reappear to each other. That allows the judge to accomplish the tasks of case management and work toward achieving its goals. And in the process, the judge's face and voice are once again seen and heard during the pretrial process.

\section{What HAPPens Then? The DAY After Judges REAPPEAR}

What if we get our wish? Imagine that federal trial judges around the country begin following the case-management practices that we associate with the Reappearing Judge. Then what? We obviously think it would result in judges conducting the pretrial process in a more visible and more efficient manner. What else might happen as a result?

In this essay, we would like to raise two possible further implications. The first is the possibility that judges might find that they are shepherding more of their cases to trial. In other words, we want to raise the possibility that Reappearing Judges might lead to some Reappearing Trials. The second is the certainty that judges will use these case-management practices only so long as they feel the time is well spent. That will depend heavily on whether the lawyers come to these various interactions informed and enthusiastic. If they do, progress can be made. But if the lawyers resist these interactions or don't adequately prepare for them, they will not work as intended.

\section{A. Might Reappearing Judges Promote Reappearing Trials?}

As discussed above, we believe that the best judicial casemanagement practices promote judicial interaction with lawyers and the clients they represent. We also believe that those case- management practices hold the potential to promote public judging in its most robust and time-honored form-trials. Here, our claim is necessarily modest 
and speculative. It is modest in that we are not talking about returning to the trial rates of the 1940s or even the 1970s. The vast majority of cases are going to settle for reasons that are not tied to how the judge conducts the pretrial process. It is speculative in that we cannot offer empirical data to show that these case-management practices will help. But both common sense and the knowledge of experienced judges show that, by minimizing pretrial costs, effective case management can make a difference as to whether cases are tried.

It is well established that most civil cases settle. ${ }^{58}$ Trial and settlement are not the only outcomes, of course. Some cases will simply be dropped by the plaintiff; ${ }^{59}$ some will be dismissed on the pleadings; ${ }^{60}$ some will terminate in a summary judgment that resolves all of the claims $;{ }^{61}$ and some will find another fate, like a dismissal resulting from sanctions. ${ }^{62}$ We are talking about the cases in which the parties choose to settle rather than proceed to trial.

Why do cases settle? According to the law and economics movement, most cases settle because in most cases settlement is the rational outcome. ${ }^{63}$ The two primary factors are (1) how closely or

58. See Theodore Eisenberg \& Charlotte Lanvers, What is the Settlement Rate and Why Should We Care?, 6 J. EMPIRICAL LEGAL STUD. 111, 115 (2009) (finding a settlement rate of approximately $67 \%$ in federal civil cases); Kevin M. Clermont, Litigation Realities Redux, 84 Notre DAME L. REV. 1919, 1954-55 (2009) (finding a settlement rate of approximately 67\%). As both studies emphasize, however, settlement statistics depend on how one defines a settlement and on how different outcomes are coded based on those definitions.

59. See FED. R. CIV. P. 41(a)(1)(A)(i) (voluntary dismissal by unilateral notice of dismissal).

60. There is no clear data on how many cases are terminated by a preanswer motion to dismiss. A 1989 study by the Federal Judicial Center found that only 3\% of the cases in that study were terminated in that manner. Thomas W. Willging, Use of Rule 12(B)(6) IN Two Federal DistRICT COURTS 2 (1989). A more recent Federal Judicial Center study of Rule 12(b)(6) motions suggests that the number may be somewhat higher, but does not pinpoint what that number might be. The more recent study found that motions to dismiss were filed in $6.2 \%$ of filed cases within ninety days of case filing. Joe S. Cecil et al., Motions to Dismiss for Failure to State a Claim AFTER IQBAL 9 (2011). The study then found that $65.9 \%$ of those cases were granted in whole or in part. Id. at 14. Because the study does not differentiate between full dismissals and partial dismissals, however, a "termination" rate cannot be calculated from the data. In addition, a true "termination" rate would have to take account of whether the motion was granted with leave to amend and, if so, whether a curative amendment was filed. See id. at 1 (finding that an opportunity to amend reduces the extent to which movants prevail by approximately ten percentage points).

61. See Joe S. Cecil \& George Cort, Report on Summary Judgment Practice Across Districts WITH VARIATIONS IN LOCAL RULES 17 tbl.12 (2008) (finding that no more than 5\% of cases are terminated by summary judgment). Another study found that the termination rate had ranged from 5\% in 1989 to $7.8 \%$ in 2000. See Joe S. Cecil et al., A Quarter-Century of Summary Judgment Practice in Six Federal District Courts, 4 J. EMPIRICAL LeGAL STUD. 861, 882-83 (2007).

62. See, e.g., FED. R. CIV. P.; Id. 37(b)(2)(A).

63. See Robert G. Bone, Civil Procedure: The Economics of Civil Procedure 71-76 (2003) (setting forth basic model for case settlement). It is true, of course, that humans are subject to 
disparately the parties value the case, and (2) the cost of litigating the case to trial. ${ }^{64}$ If the aggregate litigation costs of both parties are greater than the difference in their case evaluations, then the parties should be expected to settle. To take a very basic example, imagine that $\mathrm{P}$ values the case at $\$ 80,000$ because $\mathrm{P}$ thinks that she has an $80 \%$ chance of winning $\$ 100,000$, while $\mathrm{D}$ values the case at $\$ 40,000$ because $\mathrm{D}$ thinks P stands only a $50 \%$ chance of winning no more than $\$ 80,000$. Based on the parties' respective valuations, there would not appear to be any settlement zone. But that valuation changes when you add in litigation costs. If it will cost $\mathrm{P} \$ 30,000$ to litigate the case, then her net recovery if she prevails is only $\$ 50,000(\$ 80,000-\$ 30,000)$. And if it will cost $\mathrm{D}$ $\$ 30,000$ to litigate the case, then D's total cost becomes $\$ 70,000$ $(\$ 40,000+\$ 30,000)$. The result is that, with litigation costs factored in, $\mathrm{P}$ should be willing to accept anything above $\$ 50,000$ and $\mathrm{D}$ should be willing to pay anything below $\$ 70,000$. Rationally, the parties should settle somewhere between $\$ 50,000$ and $\$ 70,000$.

The modern pretrial process intersects with both of the dominant variables. ${ }^{65}$ First, the process is designed to clarify the scope of the suit and provide parties with access to information about the claims and defenses at issue. Under prior procedural schemes that lacked robust discovery mechanisms, the trial was often the first time the parties would actually see the other side's documents or hear what their witnesses had to say. ${ }^{66}$ In a system with broad discovery, however, the information that

cognitive limits and biases that cause them to make choices that depart from those one would expect from the ruthless utility optimizers that populate law and economics formulas. See Russell B. Korobkin \& Thomas S. Ulen, Law and Behavioral Science: Removing the Rationality Assumption from Law and Economics, 88 CALIF. L. REV. 1051, passim (2000) (discussing limits of rational choice theory and identifying ways in which "bounded rationality" and context affect choices). See also BEHAVIORAL LAW \& ECONOMICS (Cass R. Sunstein ed., 2000). That appreciation, however, does not undermine the basic notion that litigants consider settlement opportunities with an eye towards maximizing their own interests, even if their ability to do so is imperfect.

64. While other factors surely play some role in the decision whether to settle, it is not clear that these other factors are strong. See Samuel R. Gross \& Kent D. Syverud, Don't Try: Civil Jury Verdicts in a System Geared to Settlement, 44 UCLA L. REV. 1, 57-58 (1996) (finding that noneconomic interests played a significant role only in medical malpractice cases where doctors appeared to be insisting on trial for public vindication).

65. See Stephen C. Yeazell, Getting What We Asked For, Getting What We Paid For, and Not Liking What We Got: The Vanishing Civil Trial, 1 J. EMPIRICAL LEGAL STUD. 943, 947-54 (2004) (modern discovery stimulates settlement because it affects both the information and the cost sides of the settlement calculus); see also Kuo-Chang Huang, Does Discovery Promote Settlement? An Empirical Answer, 6 J. EMPIRICAL LEGAL STUD. 241, 246 (2009) ("Discovery has two potential effects on the above settlement condition. One affects the parties' subjective estimates of trial outcome and the other affects litigation costs.").

66. See John H. Langbein, The Disappearance of Civil Trial in the United States, 122 YALE L.J. 522, 530-32 (2012). 
parties need to predict outcomes and to price claims is intended to be available through the discovery process. In a "cards on the table" scheme, it is increasingly likely that the parties' respective valuations will converge, which in turn will make it increasingly likely that a settlement zone will appear once litigation costs are factored in. ${ }^{67}$ As Professor Langbein recently put it, "[h] $[\mathrm{aving}$ seen the dress rehearsal, today's litigants often find that they can dispense with the scheduled performance." 68 The dress rehearsal lets those making the decisions better understand - and often reach agreement on-whether the show will be a flop or a hit, and how much profit or loss it is likely to generate. ${ }^{69}$ The original rule drafters fully understood that one of the side effects of discovery would be providing parties with the information needed to reach pretrial settlements. ${ }^{70}$ Indeed, that impact was more than just understood-it was intended. ${ }^{71}$

The second major variable is the cost. As discussed above, increased litigation costs make settlement more likely because they reduce the net value of a victory for the plaintiff while increasing the net cost to the

67. See Lucian Arye Bebchuk, Litigation and Settlement Under Imperfect Information, 15 RAND J. ECON. 404, 413 (1984) (asserting that discovery increases the likelihood of settlement because it reduces informational asymmetry and consequently contracts the range of likely valuations); Robert D. Cooter \& Daniel L. Rubinfeld, An Economic Model of Legal Discovery, 23 J. LEGAL STUD. 435, 439 (1994) ("The first purpose of discovery is to increase the probability of settlement. This purpose is achieved by enabling the parties in a dispute to pool information so as to predict the outcomes of a trial more accurately."). For an empirical study supporting this impact, see Huang, supra note 65 , at 270-71 (finding a persistent and statistically significant rise in settlements after Taiwan adopted civil discovery provisions).

68. Langbein, supra note 66, at 551.

69. Another way of putting the point is that trials are most likely to occur when the parties have very different views about whether the "dress rehearsal" of pretrial went well. See Gross \& Syverud, supra note 64, at 60 (1996) (finding that the cases most likely to go to trial are those "in which the parties remain so far apart in their predictions of the decision on liability that they are willing to gamble on a jury's notoriously unpredictable verdict").

70. See Edson R. Sunderland, Scope and Method of Discovery Before Trial, 42 YALE L.J. 863, 865 (1933) ("Many a case would be settled, to the advantage of the parties and to the relief of the court, if the true situation could be disclosed before the trial begins.").

71. See William A. Glaser, Pretrial Discovery and the AdVersary System 11 (1968) ("[D]iscovery was expected to reduce the number of trials and thus relieve the burden on the courts. . . If both sides knew the full truth and each other's strengths and weaknesses, they would settle the case and avoid the costs and uncertainties of trial."); Patrick E. Higginbotham, So Why Do We Call Them Trial Courts?, 55 SMU L. REV. 1405, 1416 (2002) ("The Federal Rules of Civil Procedure adopted in 1938 held out the great hope that full and early disclosure of facts would facilitate settlement. Its very ambition was to reduce the number of trials by granting easy access to an opponent's possible evidence ...."); William W. Schwarzer, Slaying the Monsters of Cost and Delay: Would Disclosure Be More Effective than Discovery?, 74 JUDICATURE 178, 178 (1991) ("Discovery was intended to provide each side with all relevant information about the case to help bring about settlement or, if not, avoid trial by ambush.”). 
defendant of defending the case. As a result, the defendant is willing to pay more to settle, the plaintiff is willing to accept less to settle, and a settlement zone can appear even if the opposing sides have significantly different valuations of the merits. The proposition that litigation costs influence settlement is not just a matter of law and economics theory. In the Federal Judicial Center's 2009 survey, roughly half of the lawyers responding reported having at least one client who had settled in circumstances where the settlement would not have occurred but for the litigation costs. ${ }^{72}$

We think visible judges can have a real impact on the cost variable through live case-management work. At every stage when the parties might consider settlement, the parties must make an estimate about the future litigation costs. ${ }^{73}$ What will that estimate be? If the judge is passive and has shown little or no interest in actively managing the case to streamline the pretrial process, establish priorities, and minimize unnecessary discovery and briefing costs, the parties will have little choice but to assume the worst. But if the judge is actively involved and demonstrates to the parties a willingness to manage toward proportionality by containing costs, the parties can at least have some basis to lower their cost predictions.

We now come to the $\$ 64,000$ question: does active case management actually hold down the costs of the pretrial process? We believestrongly - that the answer is yes. ${ }^{74}$ In large part, that belief flows from

72. Emery G. Lee III and Thomas E. Willging, Federal Judicial Ctr, CASE-Based CiviL RULES SURVEY 73 (2009); see also AM. COLL. OF TRIAL LAWYERS \& INST. FOR THE ADVANCEMENT of the Am. Legal Sys., Final Report on the Joint Project of the American College of TRIAL LAWYERS TASK FORCE ON DISCOVERY AND THE INSTITUTE FOR THE ADVANCEMENT OF THE AMERICAN LEGAL SYSTEM 2 (2009) ("Some ... cases of questionable merit and smaller cases are settled rather than tried because it costs too much to litigate them."); ABA SURVEY, supra note 36, at 157 (citing survey results that $83 \%$ of respondents believe cost forces cases to settle contrary to the merits).

73. For our purposes, we will accept the idea that parties will not consider the costs to date on the grounds that the parties will rationally conclude that those costs are sunk. See BONE, supra note 63, at 91-94 (asserting that when determining whether to settle parties will consider only their future costs and not the "sunk costs" they have already incurred). We suspect, however, that the shadow of past expense in fact hangs over the process in many cases and influences decision-making about whether to proceed or settle.

74. For now, we must rely on our informed beliefs because there is no empirical data (that we are aware of) that substantiates the claim. Case-management critics sometimes point to the 1996 RAND survey as evidence that case management not only fails to cut pretrial costs but actually increases them. See Stephen B. Burbank, Keeping Our Ambition Under Control: The Limits of Data and Inference in Searching for the Cause and Consequences of Vanishing Trials in Federal Court, 1 J. EMPIRICAl Legal Stud. 571, 589 (2004) (citing JAMES S. KAKALIK ET AL., RAND InST. FOR Civil Justice, Just, SPEedy, and InEXPENSIVE? AN Evaluation of Judicial CASE 
the experiences of Judge Rosenthal and others in managing their cases. It also flows from what we know about the pretrial process generally and what lawyers tell us about what impacts pretrial costs. We know that discovery is often - though by no means always - a large pretrial expense. $^{75}$ Lawyers consistently report that early judicial management helps to limit discovery. ${ }^{76}$ We also know that summary-judgment motions drive up the cost of the pretrial process. ${ }^{77}$ In our experience, active management of the summary-judgment process can avoid much of that expense, principally by avoiding the excessive amount of protective briefing - and the exhaustive discovery to prepare for that briefing - the parties feel compelled to do when they have to assume that all issues are in play and all facts might be disputed. ${ }^{78}$

MANAgEMENT Under the CiVIL Justice Reform ACT 54, 90 (1996)) (“[W]e know that early judicial management can have the unintended effect of increasing the cost of litigation."). The 1996 RAND study, however, offers little insight into our particular proposal. For one thing, the RAND study, while nominally addressing "case-management" practices, examined a very different type of case management than we are talking about. In that study, a court was considered to exercise "early case management" simply by virtue of holding a Rule 16 conference or requiring the parties to develop and submit a joint proposed discovery plan. See KAKALIK ET AL., supra, at 14. Those criteria tell us nothing about whether the judge engaged with the parties on the merits and asked hard questions about the parties' discovery needs and priorities. Second, the data was collected from a five-year period running from 1991 to 1995 . Id. at 5. On average, the data is twenty years old, and it all pre-dated the advent of electronic discovery. Third, and most critically, the RAND study never concluded that early case management increased costs. It did find that costs increased when there was management without planning. See James S. Kakalik et al., Discovery Management: Further Analysis of the Civil Justice Reform Act Evaluation Data, 39 B.C. L. REV. 613, 653 (1998). But when the early management included discovery and case-management planning, the initial extra investment of time paid offsetting dividends later. Id. at 653-54.

75. Gathering hard data about discovery costs is difficult, to say the least. That information is not recorded in the court statistics compiled and published annually by the Administrative Office of the United States courts, but instead must be collected from clients and counsel. Collection is complicated by the fact that clients and lawyers typically do not comprehensively track "discovery" expenses in any systematic way - especially costs borne by the client in their in-house departments or IT departments. And even when such information is available, clients and lawyers are oftentimes reluctant to share it. For a discussion of these difficulties, see PACE \& ZAKARAS, supra note 24, at $3-4$.

76. Emery G. LeE III \& ThOmas Willging, Federal Judicial Ctr, Attorney Satisfaction with the Federal Rules of Civil Procedure 9 (2010); Thomas E. Willging, et al., An Empirical Study of Discovery and Disclosure Practice Under the 1993 Federal Rule Amendments, 39 B.C. L. REV. 525, 584-88 (1998) (lawyers responded that increased judicial case management was "the clear choice" for reducing cost and delay in discovery); see also ABA SURVEY, supra note 36, at 124-25 (substantial majority of lawyers surveyed responded that early judicial intervention helps to narrow the issues and limit discovery).

77. See Emery G. Lee III \& Thomas E. Willging, Federal Judicial Ctr, Litigation COSTS IN CiVIL CASES: Multivariate ANALYSIS 6, 8 (2010) (holding all other factors constant, the presence of a ruling on a summary-judgment motion was associated with a $24 \%$ increase in expense for plaintiffs and a $22 \%$ increase in expense for defendants).

78. See Gensler \& Rosenthal, supra note 28 at 549-55. 
We won't belabor the point. We know that we can offer only circumstantial and anecdotal evidence to support the conclusion that the case-management practices we associate with a Reappearing Judge can reduce pretrial costs. There is, perhaps, a more relevant way to frame the question: do lawyers and parties believe that judges committed to the active case-management practices we advocate will control the pretrial costs? If they do, then the parties should be expected to reduce their estimates of what the future litigation costs will be. As a result, judges who use those practices just may find that they are able to shepherd more of their cases to trial. ${ }^{79}$ After all, that is the essence of what lawyers have been telling us for years: if you want to increase the number of cases that reach trial, reduce the cost of getting there.

\section{B. Practicing Before the Reappearing Judge: Making It Time Well Spent for Everyone}

So far, we have focused on what judges can do to increase the opportunities for judge-lawyer interaction. We now turn to the role of the lawyers - and the clients they represent - in a court system with Reappearing Judges. Specifically, we want to examine what Reappearing Judges need from the lawyers if these increased opportunities for interaction are to thrive and continue.

What Reappearing Judges need are lawyers who will match their effort. The critical question is - to misquote the film Field of Dreamsif the judges build it, will the lawyers come? ${ }^{80}$ More to the point, will the lawyers come prepared to play? Will they come prepared to talk about their cases and answer questions, whether about discovery needs and priorities or about what issues are genuinely in dispute in the case and why? Will they have the information they need to be an advocate for their clients at these events? In short, will they take advantage of these opportunities to interact with the judge, or will they approach them as

79. See Peckham, supra note 26, at 277 ("The proper exercise of case management ... does not preclude those parties who desire to do so from going to trial. Case management is merely the means of reducing costs for those litigants who will eventually settle a case and for those litigants who want their day in court." (emphasis added)); Young, Open Letter, supra note 2, at 33 ("The truth of the matter is that good case management and traditional adjudications go hand in hand.").

80. During a pivotal scene in the movie, the main character is walking through his cornfield when he hears a disembodied voice whisper "If you build it, he will come." Field of Dreams (Gordon Co. 1989). The reference, we later discover, is to the main character's deceased father. However, the film is often misquoted as containing the line "If you build it, they will come." 
obligations to be endured - as one more hoop to jump through — and do only as much as they think is needed to "get by"?

If judicial case management is to reach its potential as a way to reconnect judges with lawyers and parties, then the lawyers and parties must embrace those opportunities. Lawyers consistently say they want active case management. ${ }^{81} \mathrm{We}$ obviously endorse that idea. But in return for judges' willingness to make themselves available and to know enough about the case to make their time with the lawyers effective, the lawyers must be prepared to provide the judges with the information they need to make sound case-specific management decisions. If the judge schedules a live Rule 16 conference, the lawyers must come prepared to engage the judge about the pretrial needs of the case. If the lawyers have held a perfunctory Rule 26(f) discovery-planning conference and still have only a vague sense of what the case is about and what discovery or motions will be needed, then the live Rule 16 conference will likely not fulfill its potential.

Lawyers also say they want judges to be available and willing to decide discovery disputes promptly, and exercise judicial supervision over discovery when that is needed. ${ }^{82}$ We support that as well. But if the judge schedules a live hearing on a discovery dispute, the lawyers must be prepared to discuss the merits of the dispute and explain why the issue matters-what difference the outcome will make in the case-with specific information about the costs, burdens, and benefits of the discovery the judge is being asked to regulate.

Finally, lawyers consistently say they want more chances to orally argue motions. ${ }^{83}$ We agree. But if the judge schedules oral argument on a motion, the lawyers must come prepared to engage the merits and not fumble around trying to remember what's in the record or, even worse, parrot their briefs.

Our point is this: for active case management to serve as a platform for interaction, the lawyers and the parties must buy in to the scheme as much as judges. The types of live case-management interactions we

81. See Gensler, supra note 11, at 687 (discussing recent lawyer surveys showing strong support for active judicial case management).

82. See Inst. FOR THE AdVAnCEMENT OF THE Am. Legal Sys., Civil Caseflow MANAGEMENT GUIDELINES 14-17 (2009) (stating that judges should play an active role in supervising discovery and should be available to expeditiously resolve discovery disputes).

83. See Kravitz, supra note 53, at 255 ("[A]t a recent hearing of the Judicial Conference's Civil Rules Advisory Committee on proposals to amend Rule 56 . . . a chief complaint of practitionersplaintiffs' and defendants' lawyers alike — was that district court judges rarely, if ever, provide an opportunity for oral argument on summary judgment motions."). 
advocate are not one-way events during which the judge does all the work while the lawyers simply observe. Rather, the value of these live interactions is that they are the best - and often the only - opportunity for the trial judge and the lawyers to have an informed dialogue that penetrates the surface gloss and exposes the core issues, whether those issues relate to priorities in discovery or the merits of a proposed summary-judgment motion. For these interactions to thrive, the attending lawyers must be prepared. This is so obvious that it hardly seems worth saying. Yet judges from different parts of the country continue to tell us that they schedule live Rule 16 conferences with the intention of developing a tailored case-management plan, only to have the lawyers say they didn't know what their pretrial needs were because they hadn't really thought about the subject. Judges tell us that they present opportunities for oral argument, only to have lawyers announce that they are resting on their briefs. That is a waste of everyone's time and a wasted chance for lawyers to interact with the judge. ${ }^{84}$

The need for lawyers to be prepared to interact is critical not just to the immediate value of the scheduled event, but also, and perhaps more importantly, to the long-term willingness of judges to conduct live conferences and hearings. Judges will do it only if it proves to be worth their time. The surest way to kill an emerging culture of interactive case management is for it to be a waste of time, and the surest way for it to be a waste of time is if the lawyers have nothing to contribute when called upon to do so. The chances for robust and successful interactions are highest when the judge communicates to lawyers in advance what the judge expects and when the lawyers come prepared with the information needed to meet those expectations. It is again an obvious point: lawyers who want the judge to spend more time being accessible must show the judge that it will be time well spent.

\section{CONCLUSION}

Judge D. Brock Hornby recently and provocatively pondered how a reality television show might depict a federal trial court judge today. ${ }^{85}$

84. In fairness, lawyers from all parts of the country have also told us of instances when they took great efforts to prepare for what they thought would be a robust and interactive Rule 16 conference only to have the judge whisk them out of the courtroom or chambers after asking only a few superficial questions related to setting pretrial deadlines. Judges can be as prone to miss opportunities as lawyers.

85. Hornby, supra note 16. 
He envisioned that the judge would be in an office in business attire, spending most of her time pounding away on a keyboard. ${ }^{86}$ His vision suggested a person tethered to the computer and all but cut off from the parties and their lawyers - a virtual judge, practically invisible. He was not describing a ratings hit or a show that critics would praise.

That may describe the days of some federal trial judges, but it does not describe their fate. It is not the immutable destiny of judges that they must vanish from sight and sound. It is certainly not the case that in order to assume the role of active case manager a judge must retreat into his or her chambers never to be seen again. Properly understood, active case management creates opportunities for judges to reconnect with the litigating public. Throughout the pretrial process, judges can conduct "live" proceedings in which they do not vanish but instead reappear. And as an added bonus, we think judges who manage their cases well will have yet another opportunity to reappear: at the trials they can sometimes foster by avoiding the crippling costs that drive parties who would like to go to trial to settle instead. That's a reality we'd like to see. 